\title{
A Check-up for the Professional Forester
}

\author{
by
}

\author{
F.L.C. Reed 1
}

The topic indicated in the program is the Forestry Challenge for Canada. To reduce the scope to manageable size, I shall speak of the challenge to professional foresters. My title is " $A$ Trip to the Clinic: A Check-up for the Professional Forester".

As an introduction, may I invite your attention first to some forestry successes and failures of the past five years, that is since the Forestry Regeneration Conference in Quebec City. Then I will identify a number of current forestry challenges which received relatively little attention a few short years back.

\section{Recent Forestry Successes}

1. Policies and Programs. We have lots of bright, new shiny forestry policies, in every province and in Ottawa. And associated with these policies in several cases are new legislation, new forest management programs, forestry school and summer student assistance, to name a few. Many companies and trade associations have adopted new policies as well.

2. Research Coordination. Another notable success is the establishment of forestry research coordination. A new Forestry Research Advisory Council, inspired by the private sector, will kick off with its first meeting in Toronto in a month's time under the chairmanship of Bruce Devitt. We also have six new federal-provincial agreements designed to enhance coordination of research at the regional level, and some others dealing with a restricted subject such as mechanized silviculture.

3. Job Creation. The implementation of a job creation program in forest renewal has proven to be a winner in the last year or so. I realize they are one-shot, discontinuous efforts, but any time you can get 15000 unemployed out in the woods doing essential silvicultural work, that is a big winner! A few weeks ago during a meeting of senior foresters on the west coast, I suggested they send a representative to Ottawa to lend a hand at the political level. Jack Toovey did just that, and in three days time managed to dig up nearly $\$ 7$ million to extend the employment bridging program in BC. The moral of the story is, don't leave it all up to the bureaucrat.

4. Fire Suppression Capability. Canada is at long last mounting a respectable fire suppression capability, thanks to a new fire protocol agreement with the United States, the newly opened Canadian Interagency Fire Fighting Centre in Winnipeg, and the forthcoming fleet of CL-215 fire bomber

'Mr. Reed was Assistant Deputy Minister for the Canadian Forestry Service when he prepared this paper for the Annual Meeting of the CIF at Sault Ste Marie. October 5, 1983. He is now with Weyerhaeuser Canada Ltd., Vancouver, BC. aircraft. Our suppression capability is well on the way toward a five-fold increase at least.

5. U.S. Collaboration. Speaking of the US, we have implemented a whole series of new cooperative agreements. These deal with containment of the mountain pine bark beetle, timber supply and demand analysis, forestry and acid rain, new softwood lumber standards, and more systematic coordination of R\&D programs. Carl Winget will be taking his eight establishment directors to the US early in 1984 for a joint meeting with his US Forest Service counterparts. This adds up to an impressive agenda which will stretch our scarce resources further and secure answers sooner.

6. Private Woodlots. A national conference at Laval University in 1981 and other concentrated efforts are now paying off with a new focus on farm woodlots management, especially in central and eastern Canada. At last they are beginning to get the attention they deserve.

7. Other Successes. We have passed another milestone with publication of a new national forest inventory report, the Maritime Forestry Complex in Fredericton will soon be a reality, and hope is mounting for an exciting new forestry research centre on the Pacific Coast. The list could be extended if time permitted.

\section{Failures}

1. Communications. With respect to print and TV coverage I believe there is at least a 10 -fold increase of forestry over five years. However, where it really counts, down at the grass roots level, in rural and urban communities alike, our forestry communications have been a complete bust. The Canadian Pulp and $\mathrm{Paper}$ Association has begun some promising work with a few school districts, and the Canadian Forestry Association struggles along on a budget that is just peanuts. This represents a waste land of missed opportunity. We shall never instill a forest land use ethic in this country until we get down into the grade schools, boy scout troops and the like.

2. Forest Renewal Performance. Another disappointing failure is the slow pace of forest renewal. Every jurisdiction is falling behind the projected level of performance in the field. Shiny policies won't buy you a cup of coffee. I include the federal government here. Only two new Forestry Development Agreements have been signed, in Nova Scotia and Prince Edward Island, since the Forest Renewal Policy was approved in August 1982. The signs of retrenchment are quite evident, quite apart from the growth we had hoped for. The targets identified in the Banff Agenda for Action in 1981 begin to look like empty promises. 
3. Federal Land Forestry. If you want a real eye-opener, take a close look at forestry practices on lands that are the responsibility of the federal government. They have to do their "mea culpa" too, just like other land owners. The neglect of forest lands on Indian reserves, on National Defence lands, and in the northern areas above 60 degrees, is a national disgrace. Once again, we are developing new programs that could be a reality by 1984 , but the record stands as I have described it.

4. R\&D Retrenchment. There is confusion and retrenchment in this area as well. The CFS was allocated an additional $\$ 5.5$ million for the present fiscal year only. Continuous funding is still being sought. Some provincial cutbacks are in the works, while industry has already pulled back. With new funds so hard to come by, it will be obvious that quality and the more selective application of existing funds will increasingly be the focus of attention. Carl Winget has just begun a new long range analysis of CFS forestry R\&D needs, together with a search for new criteria for evaluating performance and a new emphasis on transferring technology to the user. The new Forestry Research Advisory Council will be expected to contribute to this exercise.

\section{Challenges}

So much for successes and failures. Let us turn now to a few of the challenges that face us today. Each of the above failures is itself a challenge, but here are some more.

1. Forestry Schools. Challenge number one has the forestry school deans scrambling. The Canadian Forestry Advisory Council has struck a small committee to examine forestry curricula, faculty depth and related matters. They want to be helpful. They do not believe that the forestry schools have had the support to which they are entitled from provinces, the industry or the profession. At least one of the larger forestry schools does not have a full-time professor of silviculture this year. This is sad in 1983.

2. Land Alienation. Withdrawal of forest land for single use is a serious problem in several provinces. The evidence developed in 1980 for the Canadian Forest Congress showed a 25 per cent reduction in the industrial timber base during the 1970's. This issue was raised at the 1982 annual meeting and I spoke to the forestry ministers at a meeting in Winnipeg recently. They in turn have requested the CFS to prepare an inventory together with recent trends. Surely this underlines even more emphatically the necessity of managing intensively the lands remaining for industrial timber production.

3. Pesticides. The entire situation with regard to chemical use is very fluid, and indeed dangerous in its implications for forest renewal and protection. There are some positive signs that logic is prevailing; for example the 1981 Royal Commission in Newfoundland prompted the resumption of spraying, the 1982 Spitzer Report in New Brunswick did much to allay fears about Reyes Syndrome and spraying, and the CPPA has taken a plunge this year by a stepped up effort in public education. Then just three weeks ago in Winnipeg the 11 forestry ministers met under the aegis of the Canadian Council of Resource and Environment Ministers, and in their closing communiqué "recognized that there is currently a need for the use of both insecticides and herbicides in managing the nation's forests'

Then on September 15, Justice Nunn of the Supreme Court of Nova Scotia handed down his decision in the herbicide case involving Nova Scotia Forest Industries. It is well written and extremely interesting, I quote from page 178:

the evidence of risk assessments clearly indicates that any risk here in Nova Scotia, if, indeed, there is a risk at all, is infinitessimaly small and many, many times less than one in a million which level, apparently, is regarded as a safe and acceptable risk by most of the world's regulatory agencies. Putting this in perspective.... the risk of cancer to a smoker is 1 in 800 and for a non-smoker continuously in the same room with smokers it is 1 in 100000 , while the risk to a person drinking two litres of water per day from a stream immediately after being sprayed (which will not happen with buffer zones) is 1 in 100000 million, or 100000 times less than 1 in a million, which, itself is regarded as a 'de minimus' risk."

Well, this adds up to some strategic high ground in the last two or three years, but there is still much uncertainty, particularly at the federal level. Even though we have probably the world's best testing and regulation procedure (a little creaky and slow at times), I perceive a little lack of consistency at the federal level in the way we approach these things. The provinces also contribute to public concern by banning the use of products that have been approved by federal agencies. That's not much help. And then they will pester the same federal agencies because they are not moving fast enough to licence new ones. It is no wonder the public is confused.

In short there is no challenge today that is more serious and more potent for disaster to forestry. Loss of approved herbicides and insecticides would set back forest renewal by a generation in many parts of this country and most emphatically on the better sites with the better growing conditions.

It is worth pausing to reflect on some remarks of Eric Hoffer, the longshore philosopher. He says that ours is a golden age of minorities in which they speak and act as if they were "the people". The trouble is that the intimidation of the majority comes at a time when traditional authority has been eroded markedly. And it is a sad fact that the majority is not ashamed of its cowardice.

4. Forestry economics. Here is an interesting challenge. Our analytical capability is woefully inadequate in Canada. We know far too little about our timber supply, consumption trends for major products, and the intricasies of evolving trade patterns. The CFS has begun work on a timber supply model, drawing on international expertise, and we have significant forest sector modeling design work in contract with the UBC forestry school under the supervision of Peter Pearse. Pressure from international competition has escalated much more rapidly than our ability to respond. One of the reasons is the way forestry economics is taught, much of it a hundred years old in basic philosophy, using imported texts, and all conducted in splendid isolation.

5. Policy Analysis. Another weakness is the absence of an effective and independent vehicle for public policy analysis, a body which would regularly focus attention on forest sector policies of governments. When the CFS distributed its Forest Sector Strategy for Canada in 1981, there was virtually no response apart from the CIF. There are several research organizations that can do this in the United States. I believe it is high time we had our own Resources for the Future to scrutinize resource management policies and performance.

\section{The Check-up}

Now to my main theme: a check list for professional foresters. Think of it as a medical check-up if you like. The nonforester in the audience can look on as they do on TV to open heart surgery. To the profession I pose 10 questions:

1. Inventory. Are you satisfied that your employer, either industry or government, has an adequate inventory for planning, harvesting, and forest renewal? Have you told your employer that you think his inventory is lousy? Again I could use the federal lands inventory to illustrate this. It's largely non-existent and leads to all sorts of bungling.

2. Planning Horizon. Now I'm going to test your eyes for $20: 20$ vision. What's your planning horizon? Do you have a 20 -year plan as an absolute minimum? Forestry development 
agreements can't be based on a series of disjointed documents. I put this guideline right at the top of the list in the CFS Forestry Renewal Policy because I knew that a bunch of the provinces and companies don't have 20 -year plans. Mr. and Mrs. Professional Forester, does your employer have a plan to which you could readily affix your professional seal?

3. Research and Development. Have you been an influence in the forestry R\&D program of your province, of the CFS of your company, of your forestry faculty? Have you examined major recent moves in your province in the scope and conduct of R\&D? The objective of R\&D is plain and simple. It's to enhance forest resource management and to stretch scarce forest renewal dollars further. I think you've got ample reason to get into the R\&D network in a thoughtful way.

4. Forestry Schools. Are you actively monitoring and supporting your forestry faculty with respect to faculty depth, research capability, course content? Who is in a better position to monitor the forestry schools? Can they really prosper without your support?

5. Licensing and Timber Sales Documents. Are you satisfied that your province is moving in the right direction, and fast enough? New Brunswick put in a new Crown lands act and implemented it in two years. Does it really take 10 years to implement a new forestry policy? Has your professional association discussed this with the provincial forest land manager?

6. Manage Intensively. Do you know the history of hauling distances for your company? St. Regis has had a policy for 30 years in Alberta: no annual variation in the hauling distance of more than five kilometres. Have you as a professional forester calculated the savings in delivered wood costs of managing near the mills in contrast to building roads to the North Pole? Now, I know you've got to have the right combination, but I'm appalled to find how few foresters, how few woodlands managers have even bothered to make the calculation.

7. Small Private Woodlots. Do you have adequate extension programs? If you're a private company then you've got an interest in this. Farm woodlots will have to be developed from Sault Ste. Marie clear to the east coast. Much of it will be considerably cheaper than what you bring out of the hinterland. So in your company or in your province, do you have an extension service that's going to cope with this, or are there plans in your province to cut back on extension services? Why don't you ring up your Forest Service and ask them what they're doing in this area.

8. Public policy analysis. How active are you? Does your voice count with the public? Five years ago the answer would have been no, no, no! Today, more and more, I see the professional forestry associations beginning to come to grips with the challenge, particularly in British Columbia.

9. Post Harvest Audit. Do you as a professional systematically examine the performance $10,20,30$ years back, after harvest or natural depletion, to see what's happened on that land within 50 miles of your mill. The results will too often show (i) an unexpected regeneration failure; (ii) a marked shift in species mix (for example from jack pine and black spruce over to balsam fir and poplar); (iii) less volume per hectare coming up in the next harvest than you had in the last one; and (iv) a longer rotation age than you had planned for. Now that's not an isolated case. I'm afraid that bad news of this kind is quite widespread in our forests. I'm reminded of a case study that Ken Armson did for me in 1978, published in "Forest Management in Canada" for the CFS. He examined the Engleheart Management Unit and I invite you to re-read it as I've done recently. And take the initiative in launching independent post-harvest audits. Bob Blanchard mentioned this today, referring to the IWA's own forest management policy. I say this to assure you I didn't originate the idea. People like Ken Hearnden and many others have called for a forestry ombudsman on numerous occasions.

10. Status of the Profession. Okay, the doctor has some bad news for you, but you're not going to get your diagnosis for a while. You're going to have to wait for two weeks yet. Meanwhile, just go home and think about the status of the professional forester in your region. How does your association support its members in professional matters in dispute? Does your employer tend to disregard the professional, or patronize him, or ignore him? Does your employer really think that he can manage the forests in competition with Sweden, and Georgia, and Oregon by replacing foresters with technicians?

\section{Ten Commandments}

Now let me recap those last 10 points. An earlier speaker mentioned The Lord's Prayer, but I would like to take you back to Moses on Mt. Sinai. Here are ten new commandments designed specifically for the professional forester. I can't say they will take you all the way to the Promised Land, but I am sure they will take you out of The Wilderness of neglect and constant backsliding:

I Demand a respectable inventory.

II Require a long term forestry plan.

III Influence the conduct of research.

IV Stand by your forestry school.

$\checkmark$ Scrutinize the forest management agreement.

VI Bring the forest back to the mill, or don't spend it all on roads

VII Strengthen woodlot extension.

VIII Compare forestry performance with policy declarations.

IX Initiate a post-harvest audit system.

$X$ Elevate the status of the professional forester

You may not have noticed that these 10 commandments can be used to rate your employer. On the way home, why don't you rate your employer on a scale of 1 to 10 . Then you might even rate yourself if you happen to be Jimmy Clark here, or indeed, Ken Armson, or Fred McDougall or George Garner. I mention these men because they are leaders in the top one percent of the forestry profession in Canada.

Are there dangers involved in doing these things? Of course, but I guarantee there will be fulfillment also. It was Somerset Maugham who said, "There is nothing so degrading as the constant anxiety about ones means of livelihood".

In closing, ladies, and gentlemen, the forestry performance has not lived up to expectations in the past five years. Sure, there is good forestry, we've got some fantastic forestry in this country. There is also some dreadful neglect and what bothers $m e$ is that the average is far too low. The Banff Agenda for Action carried targets; these targets will never be met in 1987 at the present pace. Why? In part because we have too much "pickup truck forestry" in this country. It's not good enough to drive through a management unit in a pickup truck, and wave to the people picking berries on the roadside and never stopping to walk through that little fringe of alder or poplar to see what's on the other side. Pickup truck forestry is worse, as far as I'm concerned, than "board room forestry".

In the 1979 Annual Meeting of the CIF, I quoted from Robert Frost. Let me do it again but l'll take a different poem this time, even though you've still got "miles to go before you sleep". Try this, the last stanza from "The Road Not Taken". You remember the one that goes, "Two roads diverged in a yellow wood, and I could not travel both and be one traveller".

"I shall be telling this with a sigh, ages and ages hence,

Two roads diverged in a yellow wood, and $I$,

I took the one less travelled by,

And that has made all the difference."

Choose wisely, professional forester! 